\title{
A Case Report on the Survivability of Marine Luminous Bacteria Vibrio campbellii STF1 under Starvation Conditions
}

\author{
Ramesh $\mathrm{CH}^{1,2 *}$ and Mohanraju $\mathbf{R}^{2}$ \\ ${ }^{1}$ Department of Ocean Studies and Marine Biology, Pondicherry University, Port Blair-744102, Andaman and Nicobar Islands, India \\ ${ }^{2}$ Andaman and Nicobar Centre for Ocean Science and Technology, ESSO-NIOT, Dollygunj, Port Blair, Andaman and Nicobar Islands-744103, India
}

Submission: November 28, 2017; Published: January 08, 2018

*Corresponding author: Ramesh CH, Andaman and Nicobar Centre for Ocean Science and Technology, ESSO-NIOT, Dollygunj, Port Blair, Andaman and Nicobar Islands-744103, India, Email: chrameshpu@gmail.com

\begin{abstract}
Recently luminous Vibrio campbellii has been recognised as a cosmopolitan pathogen in seafood and aquaculture industry. The significance of this study is to present the findings derived from longer-term starvation experiment on intense luminescence producing bacteria Vibrio campbellii strain STF1. This strain was isolated from surface swab of Synanceia verrucosa (stone fish) and subjected to the starvation-survival procedure. The viability rate of this culture was determined following spread plate method by counting viable cells in starter inoculum and in the same starvation culture. It was observed that 90 to $95 \%$ of luminous bacteria could remain viable for over 4 years under nutrient deficiency condition. This study also determines the effectiveness of the preservation of luminous bacteria in sterile sweater.
\end{abstract}

Keywords: Luminous bacteria; Vibrio campbellii; Starvation; Survival

\section{Introduction}

Nutrients are one of the main factors that are necessary for the survival of any microorganism or macro organism. Marine bacterial communities possess enormous potentiality to produce diverse striking traits such as production of pigments, secondary metabolites, forming magnetosomes, emission of fluorescence and bioluminescence [1]. To display these peculiar features, bacteria require continuous nutrient supplement either in natural environment or at laboratory conditions. In spite of these features, bacteria also require nutrients for the intracellular metabolism, and nutrient deficiency would lead to cell shrinking and subsequently to death. Several studies had shown the survival of different bacterial species under nutrient deficient conditions for hours or days [2].

Storage of luminous bacterial cultures in lyophilization and cryogenic methods are established practices in many laboratories for longer period and under liquid paraffin or agar slants or stabs for a short-term period of 3 to 6 months. In contrast to these methods, the present study was planned and undertaken four years ago to understand the long term survival capability of a luminous bacteria Vibrio campbellii STF1 under nutrient deficient condition whether it is alive or dead. This luminous bacterium was isolated from surface swab of stone fish Synanceia verrucosa on Seawater complete agar medium and identified as Vibrio campbellii based on 16s rRNA sequence analysis [3].

\section{Materials and Methods}

\section{Starvation-survival test \& viability assay}

Freshly isolated luminous bacteria Vibrio campbellii was subjected to a simple starvation-survival procedure by transferring $200 \mu \mathrm{l}$ of overnight grown culture in marine broth into $2 \mathrm{ml}$ Eppendorf tube containing $980 \mu \mathrm{l}$ of sterile sea water. Viability assay was determined by spread plate method by determination of colony forming units (CFU) in the initial inoculum and viable cells after 4 years starvation process.

\section{Results and Discussion}

It was apparent that the initial inoculum has high $\mathrm{CFU}$ value of $4.2 \times 103 \mathrm{~mL}-1$ and by fourth year the culture CFU value was $3.8 \times 103 \mathrm{~mL}-1$, indicating that these bacteria have not greatly decreased. The colony morphology also remained same as initial inoculum. This practice is insuring the longevity and 
maintenance of luminous bacterial culture characteristics for longer period. It was inferred that the prolonged starvation induces formation of stress-resistant ultra microcells by vibrios and there by induces release of stress proteins by set of core genes to survive stress conditions [2]. However, we have not addressed such genetical features in this study and clearly V. campbellii could able to survive up to four years without any morphological changes at room temperature, and probably would survive for longer period.

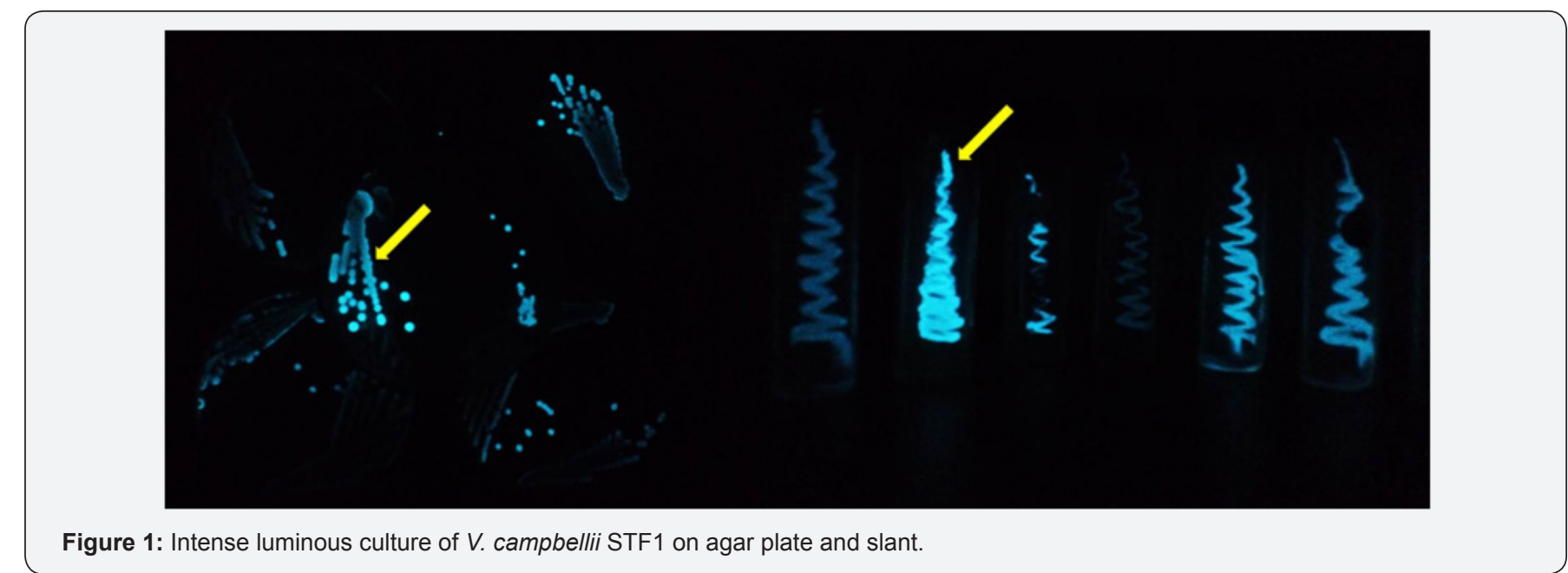

It was inferred that the longevity time of survival of bacterial species depends on the species and nutrients available in the given medium. Recently, luminous Photobacterium phosphoreum and $\mathrm{Ph}$. splendidum isolated by Martinus W. Beijerinck and stored in $15 \mathrm{ml}$ glass ampoules during 1924 and 1925 were revived after 80 years [4]. These strains were stored in nutrient rich broth medium that containing fish extract water prepared by boiling fish in natural, clean seawater, and adding $10 \% \mathrm{w} / \mathrm{v}$ chalk [5]. In contrast to these strains, it is not apparent how the luminous STF1 survived in sea water, since this luminous bacterium is negative to spore forming and also negative to accumulate intracellular carbon source i.e. polyhydroxybutyrate. The only probability is involvement of other cell constituents to avoiding the starvation by reduced metabolic rate.

\section{Conclusion}

The bacterial culture Vibrio campbellii strain STF1 in $2 \mathrm{~m}$ Eppendorf tube is still stored in an amber coloured bottle at room temperature for future monitoring and further author is focusing on whole genome sequence analysis of this strain. We also infer that storage of luminous bacteria in liquid sterile seawater with addition of nutrients would keep bacteria alive for longer period as seen in this study.

\section{Acknowledgement}

The corresponding author thanks the Department of Science and Technology for providing the INSPIRE fellowship/DST/ IF120230.

\section{References}

1. Ramesh CH (2016) Studies on marine bioluminescent bacteria from Andaman Islands. PhD Thesis, Pondicherry University, India.

2. Kjelleberg S (1993) Starvation in Bacteria. Springer Science+Business Media, New York, USA.

3. Ramesh CH, Mohanraju R, Murthy KN, Karthick P, Narayana S (2014) Impact of light, temperature, salinity and glycerol on the intensity of luminescence and growth of marine bioluminescent bacteria Vibrio campbellii (strain STF1). Curr Sci 106(4): 511-513.

4. Figge MJ, Robertson LA, Ast JC, Dunlap PV (2011) Historical microbiology: revival and phylogenetic characterization of luminous bacterial cultures of M. W. Beijerinck. FEMS Microbiol Ecol 78(3): 463472.

5. Robertson LA, Figge MJ, Dunlap PV (2011) Beijerinck and the bioluminescent bacteria: microbiological experiments in the late $19^{\text {th }}$ and early $20^{\text {th }}$ centuries. FEMS Microbiol Ecol 75(2): 185-194. 
This work is licensed under Creative Commons Attribution 4.0 Licens

DOI: 10.19080/OFOAJ.2018.05.555671
Your next submission with Juniper Publishers will reach you the below assets

- Quality Editorial service

- Swift Peer Review

- Reprints availability

- E-prints Service

- Manuscript Podcast for convenient understanding

- Global attainment for your research

- Manuscript accessibility in different formats ( Pdf, E-pub, Full Text, Audio)

- Unceasing customer service

Track the below URL for one-step submission https://juniperpublishers.com/online-submission.php 